\title{
Pengaruh Stres Dan Konflik Kerja Terhadap Kinerja Karyawan PT. Citra Aqila Proteksi Medan
}

\author{
Taufiq Risal ${ }^{\mathrm{a}, 1}$, Tika Nirmala Sari ${ }^{\mathrm{b}, 2}$ \\ a,b Fakultas Ekonomi dan Bisnis, Program Studi Manajemen, Universitas Potensi Utama, \\ Jl. K.L.Yos Sudarso, Tj. Mulia, Medan Deli, Kota Medan-20241Telp: (061) 6640525, \\ e-mail: jifarkan@gmail.com ${ }^{1}$, t.nirmalasari@gmail.com²
}

\begin{abstract}
ABSTRAK
Penelitian ini bertujuan untuk mengetahui dampak konflik dan stres kerja terhadap kinerja karyawan PT. Citra Aqila Proteksi (CAP). Populasi penelitian ini berjumlah 43 orang karyawan PT. CAP. Jumlah sampel adalah 43 orang karyawan PT CAP dengan teknik pengambilan sampel jenuh. Data diperoleh dari survei dan penyebaran kuesioner penelitian terhadap karyawan PT. CAP. Teknik analisis menggunakan analisis regresi linier berganda. Hasil penelitian ini menunjukan bahwa secara serempak Stress dan Konflik Kerja berpengaruh signifikan terhadap Kinerja Karyawan. Secara parsial, variabel Stress dan Konflik Kerja masing-masing berpengaruhnegatifdan signifikan bagi Kinerja Karyawan.
\end{abstract}

Kata Kunci : Stress Kerja, Konflik Kerja, Kinerja Karyawan

\begin{abstract}
The purpose of this study is to find out the influence of conflict and work stress on performance of PT. Citra Aqila Proteksi (PT. CAP) employees. The population of this study amounted to 43 employees of PT. CAP. The sample number is 43 employees of PT CAP with saturated sampling techniques. Data obtained from surveys and dissemination of research questionnaires to employees of PT. CAP. Analytical techniques use multiple linear regression analysis. The results of this study show that simultaneously Stress and Work Conflicts have a significant effect on Employee Performance. Partially, stress and conflict-of-work variables each negatively and significantly affect employee performance.
\end{abstract}

Keywords : Work Stress, Work Conflict, Employee Performance

$\begin{array}{cc}\text { Info Artikel : } & \text { Diterima :23 Januari } 2021\end{array}$

Copyright $($ C) 2022 - Journal UPU. All rights reserved.

\section{PENDAHULUAN}

Manajemen Sumber Daya Manusia memiliki tugas untuk mengelola unsur manusia secara baik agar diperoleh tenaga kerja yang berkualitas. Setiap perusahaan pasti membutuhkan sumber daya manusia berkinerja baik agar mencapai tujuannya. Dalam menghadapi perubahan yang sering terjadi, didalam perusahaan dapat terjadi konflik dan stres yang pada akhirnya menimbulkan suatu kesenjangan. Bagi sebuah perusahaan, perlu untuk membuat karyawannya dapat melakukan pekerjaan dalam keadaan setenang dan senyaman mungkin, tanpa ada perasaan cemas. Kondisi ini tidak hanya terkait dengan kondisi fisik, tetapi juga dengan orang lain dan suasana psikologis di tempat kerja. Suasana kerja yang menyenangkan akan memungkinkan karyawan bekerja secara maksimal.

Kinerja karyawan merupakan salah satu faktor yang memegang peranan penting dalam mencapai tujuan perusahaan maupun tujuan individu. Pencapaian tujuan perusahaan diperoleh dari upaya perusahaan dalam mengelolah sumber daya manusia yang berpotensi agar dapat meningkatkan hasil kerjanya. Akan sulit bagi perusahaan untuk mencapai tujuannya jika karyawannya tidak berkinerja baik. Untuk mencapai tujuan tersebut diperlukan pegawai yang berdedikasi, loyal, patuh, disiplin dan bertanggung jawab atas semua pekerjaan yang ditugaskan dan dilaksanakan. 
Kinerja (prestasi kerja) adalah hasil kerja secara kualitas dan kuantitas yang dicapai oleh seorang pegawai dalam melaksanakan tugasnya sesuai dengan tanggung jawab yang diberikan kepadanya. Pendapat lain bahwa kinerja adalah penentuan secara periodik efektivitas operasional organisasi, bagian organisasi dan karyawannya berdasarkan sasaran, standar dan kriteria yang telah ditetapkan sebelumnya.

Hal-hal yang dinilai dalam kinerja dapat berupa: Jumlah kerja yang dilakukan dalam suatuperiode yang ditentukan (Quantity of Work), Kualitas kerja yang dicapai berdasarkan syarat-syarat kesesuaian dan kesiapannya (Quality of Work), Luasnya pengetahuan mengenai pekerjaan dan keterampilannya ( Job Knowledge), Keaslian gagasan-gagasan yang dimunculkandan tindakantindakan untuk menyelesaikan persoalan-persoalan yang timbul (Creativeness), Kesediaan untuk bekerjasama dengan orang lain atau sesama anggota organisasi (Cooperation), Kesadaran untuk dapat dipercaya dalam hal kehadiran dan penyelesaian kerja (Dependability), Semangat untuk melaksanakan tugas-tugas baru dan dalam memperbesar tanggungjawabnya (Initiativ), Menyangkut kepribadian, kepemimpinan, keramahtamahan, dan integritas pribadi (Personal Qualities).

PT. Citra Aqila Proteksi (PT. CAP) Medan dalam menentukan kinerja karyawan dilakukan melalui penilaian dan evaluasi kinerja karyawan. Penilaian kinerja ini dilakukan satu tahun sekali pada bulan Desember dan dinilai oleh Departemen SDM. Penilaian kinerja karyawan ditentukan dengan aspek-aspek yaitu aspek integritas, aspek kedisiplinan, aspek pengetahuan pekerjaan, aspek kualitas dan kuantitas kerja, aspek semangat berprestasi dan aspek kerjasama. Aspek-aspek penilaian kinerja yang terdiri dari enam aspek tersebut yang kemudian pada saat penilaian dicocokkan dengan standar nilai untuk menentukan kinerja seperti yang ada di tabel 1.

Tabel 1. Standar Nilai Kinerja Karyawan PT. CAP

\begin{tabular}{|c|c|r|}
\hline No. & Nilai & \multicolumn{2}{|c|}{ Keterangan } \\
\hline 1 & $90-100$ & Baik Sekali \\
2 & $80-89$ & Baik \\
3 & $70-79$ & Cukup \\
4 & $60-69$ & Kurang \\
5 & $<60$ & Kurang Sekali \\
\hline
\end{tabular}

Sumber: PT. Citra Aqila Proteksi (2021)

Standar yang terdapat dalam Tabel 1 ini kemudian digunakan untuk menentukan kinerja karyawan di PT. CAP. Hasil Penilaian Kinerja Karyawan pada PT. CAP periode 2018 - 2020 dapat dilihat pada tabel 2 .

Tabel 2. Penilaian Kinerja Karyawan pada PT. CAP periode 2018 - 2020

\begin{tabular}{|c|l|r|c|r|r|r|r|}
\hline No & \multicolumn{1}{|c|}{$\begin{array}{c}\text { Aspek } \\
\text { Penilaian }\end{array}$} & \multicolumn{2}{|c|}{$\mathbf{2 0 1 8}$} & \multicolumn{2}{|c|}{ 2019 } & \multicolumn{2}{|c|}{ 2020 } \\
\cline { 3 - 8 } & Nilai & Keterangan & Nilai & Keterangan & Nilai & Keterangan \\
\hline 2 & Integritas & 91 & Baik Sekali & 92 & Baik Sekali & 84 & Baik \\
\hline 3 & Kedisiplinan & 85 & Baik & 82 & Baik & 71 & Cukup \\
\hline 4 & $\begin{array}{l}\text { Pengetahuan } \\
\text { Pekerjaan }\end{array}$ & 86 & Baik & 85 & Baik & 86 & Baik \\
& $\begin{array}{l}\text { Kualitas dan } \\
\text { Kuantitas } \\
\text { Kerja }\end{array}$ & 90 & Baik Sekali & 91 & Baik Sekali & 84 & Baik \\
\hline 5 & Semangat & 88 & Baik & 85 & Baik & 72 & Cukup \\
\hline 6 & Kerjasama & 88 & Baik & 88 & Baik & 80 & Baik \\
\hline & 528 & & 523 & & 473 & \\
\hline & & 88 & Baik & 87 & Baik & 79 & Cukup \\
\hline
\end{tabular}

Sumber: PT. Citra Aqila Proteksi (2021)

Pada Tabel 2 dapat dilihat bahwa rata-rata kinerja karyawan PT. CAP Medan terjadi penurunan dari tahun ke tahun, untuk tahun 2018 ke tahun 2019 penurunannya hanya 0,17 persen, namun terlihat penurunan yang signifikan terjadi pada tahun 2019 ke tahun 2020 sebesar 7,67 persen. 
Memang umumnya dalam suatu organisasi, selalu ada permasalahan yang dapat menurunkan kinerja karyawan, baik diantara individu maupun kelompok yang menyangkut kepentingan masingmasing. Permasalahan tersebut akan menimbulkan stress dan konflik dalam bekerja. Biasanya umumnya stress dan konflik menimbulkan dampak negatif. Tapi ada juga yang menimbulkan dampak positif (eustress dan konflik fungsional bagi perusahaan). Tergantung bagaimana mengarahkan konflik dan stres tersebut sehingga menjadi konflik dan stres yang bermanfaat bagi perusahaan dan karyawan.

Berdasarkan hasil observasi, penulis juga menemukan adanya permasalahan sesuai dengan aspek kinerja, antara lain: kedisiplinan dan semangat kerja yang menurun, permasalahan dilihat dari banyaknya karyawan yang mangkir saat jam kerja dan jam istrahat makan siang telah selesai karyawan seharusnya kembali ke meja kerja masing-masing tetapi pada kenyataannya masih banyak yang belum berada dimeja kerjanya sehingga terlambat masuk dan pekerjaannya-pun terabaikan.

Hasil pra survey pada table 3, menunjukkan bahwa stres kerja akibat tekanan waktu dan melakukan pekerjaan yang bukan jobdesk menjadi faktor yang kuat yang dapat menyebabkan karyawan mengalami stres kerja. Hal ini terlihat dari persentasi masing-masing sebesar 55 persen dan 60 persen. Sementara untuk beban kerja, hal ini ternyata banyak membuat karyawan lebih bersemangat untuk menyelesaikan kerjanya agar bisa lebih cepat istrahat dan bersantai. Terlihat dari persentasi atas pertanyaan beban kerja membuat semakin bersemangat dengan persentasi 65 persen responden menjawab "Ya".

Selanjutnya, hasil pra survey juga menunjukan bahwa konflik kerja yang terjadi, disebabkan oleh tidak terpenuhinya hak dan kewajiban oleh perusahaan disetujui oleh 70 persen responden. Juga mengenai respon atau solusi yang buruk dari perusahaan terhadap masalah pekerjaan, disetujui 70 persen responden. Hal ini dapat dikategorikan sebagai konflik interorganisasi. Sementara untuk konflik interpersonal seperti perbedaan pendapat yang dapat menyebabkan konflik dan kecemburuan sesama karyawan menunjukan persentasi yang rendah yaitu disetujui oleh masing-masing 45 persen dan 25 persen responden.

Tabel 3. Hasil Pra-Survey kinerja karyawan PT. CAP akibat stress dan konflik kerja

\begin{tabular}{|c|l|r|c|}
\hline Variabel & Penilaian & $\begin{array}{c}\text { Setuju } \\
(\mathbf{\%})\end{array}$ & $\begin{array}{c}\text { Tidak Setuju } \\
(\boldsymbol{\%})\end{array}$ \\
\hline \multirow{2}{*}{$\begin{array}{c}\text { Stress } \\
\text { Kerja }\end{array}$} & Waktu kerja yang sempit & 55 & \multicolumn{1}{c|}{45} \\
\cline { 2 - 4 } & Beban Kerja membuat stres & 35 & 65 \\
\cline { 2 - 4 } & Melakukan pekerjaan bukan Job desk & 60 & 40 \\
\hline \multirow{2}{*}{$\begin{array}{c}\text { Konflik } \\
\text { Kerja }\end{array}$} & $\begin{array}{l}\text { Adanya perbedaan pendapat yang menjadi } \\
\text { penyebab konflik }\end{array}$ & 45 & 55 \\
\cline { 2 - 4 } & Kecemburuan/iri hati sesame karyawan & 25 & 75 \\
\cline { 2 - 4 } & Solusi yang buruk dari perusahaan & 70 & 30 \\
\cline { 2 - 4 } & $\begin{array}{l}\text { Tidak terpenuhinya hak karyawan oleh } \\
\text { perusahaan }\end{array}$ & 70 & 30 \\
\hline
\end{tabular}

Sumber: PT. Citra Aqila Proteksi (2021)

Terlihat bahwa, stres yang dialami oleh karyawan diduga diakibatkan adanya pekerjaan yang dilakukan bukan jobdesknya, seperti pekerjaan lapangan yang seharusnya dilakukan oleh staf namun dilakukan oleh karyawan bagian administrasi. Atau juga seringnya karyawan melakukan pekerjaan dengan diburu waktu oleh atasannya.

Disisi lain, karyawan diduga sering mengalami konflik dengan pihak perusahaan terkait masalah perpanjangan kontrak kerja dan tidak transparannya upah yang dibayarkan setiap bulannya.

Stress dan konflik yang terjadi di dalam perusahaan, baik konflik interpersonal dan interorganisasi, apabila tidak ada pengamanan yang tepat, maka dapat berimbas pada menurunnya kinerja karyawan, sehingga dapat berdampak pada reputasi PT. CAP dimata konsumen yang memakai jasanya. Dengan berdasarkan uraian yang ada ini, maka penulis sangat berkeinginan 
melakukan penelitian dengan judul "Pengaruh Stres dan Konflik Tempat Kerja Terhadap Kinerja Karyawan Pada PT. Citra Aqila Proteksi.

\section{TINJAUAN PUSTAKA}

Kinerja adalah gambaran prestasi kerja yang dilakukan oleh seseorang dalam melaksanakan tugas yang dibebankan kepadanya sesuai dengan keahlian, pengalaman dan kesungguhan pada waktu tertentu (Hasibuan,2016).

Menurut Armstrong dan Baron (dalam Wibowo, 2007) ada beberapa faktor yang mempengaruhi kinerja antara lain:

1. Faktor-faktor pribadi diantaranya kemampuan individu, kompetensi, motivasi dan komitmen.

2. Faktor-faktor kepemimpinan diantaranya kualitas dorongan, bimbingan, dan dukungan yang disediakan oleh pimpinan dan pemimpin lain.

3. Faktor-faktor tim diantaranya kualitas dukungan yang disediakan oleh rekan kerja.

4. Faktor-faktor sistem diantaranya sistem kerja dan fasilitas yang disediakan oleh organisasi.

5. Faktor-faktor situasional diantanya tekanan lingkungan internal dan eksternal serta perubahanperubahan.

Menurut Mondy dan Noe (dalam Suwanto dan Priansa,2013) penilaian kinerja merupakan suatu sistem formal yang secara berkala untuk mengevaluasi kinerja individu dalam menjalankan tugas tugasnya. Penilaian individu ini sangat penting manfaatnya bagi dinamika pertumbuhan suatu organisasi secara keseluruhan sehingga melalui kondisi tersebut maka dapat diketahui kondisi sebenarnya dari kinerja karyawan yang ada.

Kinerja Karyawan ini bisa diukur dengan mengacu pada 8 indikator (Gomes,2013) kinerja karyawan, yaitu:

1. Kuantitas kerja yaitu jumlah atau volume pekerjaan yang dikerjakan dalam periode waktu yang telah ditentukan.

2. Kualitas kerja yaitu kualitas dari pekerjaan yang telah dilakukan sesuai

3. dengan standar perusahaan.

4. Pengetahuan kerja yaitu pengetahuan mengenai pekerjaan yang akan dikerjakan, keterampilan, dan perusahaan tempat bekerja.

5. Kreatifitas yaitu keaslian dari ide-ide dan gagasan yang dikeluarkan dalam menghadapi permasalahan.

6. Kerja sama yaitu kesediaan untuk bekerjasama dengan orang lain atau rekan kerja dalam perusahaan.

7. Kesadaran yaitu kondisi sadar untuk dapat dipercaya dalam kerja.

8. Inisiatif yaitu energi memotivasi untuk melaksanakan tugas - tugas baru yang dapat mngembangkan tanggung jawabnya.

9. Kualitas pribadi yaitu menyangkut pembawaan pribadi, keperibadian, sikap, ramah tamah, dan integritas pribadi.

Stres adalah reaksi negatif dari orang-orang yang mengalami tekanan berlebih yang dibebankan kepada mereka akibat tuntutan, hambatan, atau peluang yang terlampau banyak (Robbins dan Coulter,2016). Secara umum, stres kerja dapat disebabkan (George dan Zakkariya, 2015) oleh:

1. Beban kerja.

Ada ketidaksesuaian antara peran yang diharapkan dan waktu serta sumber daya yang tersedia untuk memenuhi persyaratan ini. Beban kerja berkaitan dengan jumlah tugas yang harus dilakukan, ketersediaan waktu dan ketersediaan sumber daya. Jika rasio ketiganya tidak seimbang, pasti tidak akan bisa menyelesaikan tugas dengan baik. Ketidakseimbangan ini dapat menyebabkan seseorang menjadi stres.

2. Konflik peran. 
Konflik peran mengacu pada perbedaan pendapat antara karyawan yang bersangkutan dan atasannya tentang tugas yang harus dilakukan. Konflik peran secara umum dapat didefinisikan sebagai terjadinya dua tekanan atau lebih secara bersamaan, sehingga kepuasan salah satu kebutuhan mengarah pada kepuasan kebutuhan tersebut. yang lain sulit. Konflik peran mengacu pada perbedaan konseptual antara karyawan dan supervisor (atau atasan) mengenai pentingnya tugas pekerjaan yang diperlukan. Hal inilah yang dapat menimbulkan konflik, konflik antara komitmen kepada banyak atasan (bos) dan nilai-nilai pribadi terkait dengan kebutuhan organisasi.

3. Ambiguitas peran.

Ambiguitas peran mengacu pada kurangnya kejelasan tugas yang harus dilakukan karyawan. Hal ini terjadi salah satunya karena atasan tidak memberikan job description yang jelas, sehingga karyawan tidak mengetahui peran apa yang harus dimainkannya dan tujuan apa yang harus didapat dengan peran tersebut.

Menurut Igor S (1997) menyatakan bahwa indikator stres kerja adalah

1. Intimidasi dan tekanan dari rekan sekerja, pimpinan perusahaan dan klien.

2. Perbedaan antara tuntutan dan sumber daya yang ada untuk melaksanakantugas dan kewajiban.

3. Ketidakcocokan dengan pekerjaan.

4. Pekerjaan yang berbahaya, membuat frustasi, membosankan atau berulang-ulang.

5. Beban lebih

6. Faktor-faktor yang diterapkan oleh diri sendiri seperti target dan harapan yang tidak realistik, kritik dan dukungan terhadap diri sendiri

Konflik adalah sebuah proses yang dimulai ketika satu pihak menjadi sadar bahwa pihak lain secara negatif mempengaruhi atau akan menimbulkan efek secara negatif sesuatu yang menjadi perhatian dan keperluan bersama (Robbins,2015). Konflik dalam interaksi dengan orang lain dalam suatu organisasi, secara garis besar dapat dikelompokkan menjadi dua bagian (Flippo,2012), yaitu;

1. Konflik Intrapersonal.

Konflik intrapersonal adalah konflik seseorang dengan dirinya sendiri. Konflik terjadi bila pada waktu yang sama seseorang memiliki dua keinginan yang tidak mungkin dipenuhi sekaligus. Sebagaimana diketahui bahwa dalam diri seseorang itu biasanya terdapat hal-hal sebagai berikut:

a. Sejumlah kebutuhan-kebutuhan dan peranan-peranaan yang bersaing,

b. Beraneka macam cara yang berbeda yang mendorong peranan- peranan dan kebutuhankebutuhan itu terlahirkan,

c. Banyaknya bentuk halangan-halangan yang bisa terjadi di antara dorongan dan tujuan,.

d. Terdapatnya baik aspek yang positif maupun negatif yang menghalangi tujuan-tujuan yang diinginkan.

Dalam proses adaptasi seseorang terhadap lingkungannya acapkali menimbulkan konflik. Ada tiga macam bentuk konflik intrapersonal yaitu:

1. Konflik pendekatan-pendekatan. Contohnya orang yang dihadapkan pada dua pilihan yang sama-sama menarik, misalnya seseorang ditawari dua pekekrjaan yang sama-sama dia sukai.

2. Konflik pendekatan-penghindaran. Contohnya orang yang dihadapkan pada dua pilihan yang sama menyulitkan, misalnya seseorang harus mengadakan pilihan dari dua pekerjaan yang mempunyai resiko sama besar.

3. Konflik penghindaran-penghindaran. Contohnya orang yang dihadapkan satu hal yang mempunyai nilai positif dan negatif sekaligus, misalnya seorang pegawai yang bekerja pada perusahaan yang begitu ketat peraturannya (sangat sulit untuk minta ijin tidak masuk kerja) tetapi mendapatkan kompensasi yang besar.

2. Konflik Interpersonal. 
Konflik Interpersonal adalah konflik orang-ke-orang karena konflik kepentingan atau keinginan. Ini biasanya terjadi antara dua orang yang berbeda status, jabatan, bidang pekerjaan dan sejenisnya. Jenis konflik ini akan melibatkan beberapa peran beberapa anggota dalam organisasi yang hanya dapat mempengaruhi proses pencapaian tujuan organisasi. Misalnya, konflik antar karyawan sering muncul karena perbedaan kepentingan. Hal ini sering terjadi antara dua orang yang berbeda status, jabatan, bidang kerja dan lain-lain. Konflik semacam ini akan melibatkan beberapa peranan dari beberapa anggota organisasi yang tidak bisa tidak akan mempengaruhi proses pencapaian tujuan organisasi tersebut. Untuk mengukur terjadinya konflik interpersonal terlihat dari :

a. adanya pertentangan antara seorang karyawan dengan karyawan lain karena kepentingan,

b. adanya pertentangan antara seorang karyawan dengan karyawan lain karena terjadinya perbedaan karakteristik,

c. adanya kelompok-kelompok karyawan, dan

d. adanya pertentangan antara seorang karyawan dengan karyawan lain karena tekanan-tekanan kelompok individu lainnya.

3. Konflik antar individu-individu dan kelompok-kelompok.

Hal ini seringkali berhubungan dengan cara individu menghadapi tekanan tekanan untuk mencapai konformitas, yang ditekankan kepada mereka oleh kelompok kerja mereka. Sebagai contoh dapat dikatakan bahwa seseorang individu dapat dihukum oleh kelompok kerjanya karena ia tidak dapat mencapai norma-norma produktivitas kelompok dimana ia berada.

4. Interorganisasi

Konflik Interorganisasi sering dikaitkan dengan persaingan yang timbul didalam perusahaanperusahaan swasta. Konflik interorganisasi sebenarnya berkaitan dengan isu yang lebih besar lagi, contohnya perselisihan serikat buruh dengan perusahaan. Dalam setiap kasus, potensi terjadinya konflik melibatkan individual yang mewakili organisasi secara keseluruhan, bukan hanya sub unit internal atau grup. Dalam suatu organisasi, konflik harus dapat dikelola untuk mencapai tujuan yang sehat. Dengan kata lain, munculnya konflik dalam organisasi harus dilihat sebagai gejala organisasi yang sehat. Dengan demikian, setiap konflik yang mungkin timbul akan diatasi dengan semangat gotong royong untuk mencapai tujuan bersama.

Suatu konflik dapat terjadi karena masing-masing pihak atau salah satu pihak merasa dirugikan. Untuk mencegah konflik, maka pertama-tama kita harus mempelajari sebab-sebab yang dapat menimbulkan konflik secara umum tersebut. Menurut Wirawan (2010) penyebab timbulnya konflik adalah sebagai berikut:

1. Keterbatasan sumber.

Manusia pada dasarnya selalu mengalami keterbatasan sumber-sumber yang diperlukan untuk mendukung kehidupan. Keterbatasan itu menimbulkan terjadinya kompetisi diantara manusia untuk mendapat sumber yang diperlukannya dan hal ini sering kali menimbulkan konflik.

2. Tujuan yang berbeda.

Konflik terjadi karena pihak-pihak yang terlibat konflik mempunyai tujuan yang berbeda. Konflik juga bisa terjadi karena tujuan pihak yang terlibat konflik sama, tetapi cara untuk mencapainya berbeda.

3. Saling tergantung atau interpedensi tugas.

Konflik bisa terjadi karena pihak-pihak yang terlibat konflik memiliki tugas yang tergantung satu sama lain. Sebagai contoh, aktivitas pihak yang satu bergantung pada aktivitas atau keputusan pihak lainnya. Jika tingkat saling ketergantungan tinggi, maka resolusi konflik akan tinggi. Jika tidak ada saling ketergantungan, maka konflik tidak akan terjadi. Jadi, konflik terjadi diantara pihak yang saling membutuhkan saling berhubungan dan tidak bisa meninggalkan satu sama lain tanpa konsekuensi negatif.

4. Diferensiasi organisasi.

Salah satu penyebab timbulnya konflik dalam organisasi adalah pembagian tugas dalam birokrasi organisasi dan spesialisasi tenaga kerja pelaksananya. Berbagai unit kerja dalam birokrasi organisasi berbeda formalitas strukturnya. Ada unit kerja yang berorientasi pada waktu penyelesaian tugas, pada hubungandan pada hasil dari tugas. Sebagai contoh, unit kerja pemasaran lebih berorientasi pada waktu jangka pendek, lebih formal dalam struktur organisasi 
dan lebih focus dalam hubungan interpersonal jika dibandingkan dengan unit kerja penelitian dan pengembangan. Perbedaan itu dapat menimbulkan konflik karena perbedaan pola pikir, perbedaan perilaku dan perbedaan pendapat mengenai sesuatu.

5. Ambiguitas yuridiksi.

Pembagian tugas yang tidak definitif akan menimbulkan ketidakjelasan cakupan tugas dan wewenang unit kerja dalam organisasi. Dalam waktu yang bersamaan, ada kecenderungan pada unit kerja untuk menambah dan memperluas tugas dan wewenangnya. Keadaan ini sering menimbulkan konflik antar unit kerja atau antar pejabat unit kerja. Konflik jenis ini banyak terjadi pada organisasi yang baru dibentuk dan belum ada pembagian tugas yang jelas.

6. Sistem imbalan yang tidak layak.

Di perusahaan, konflik antara karyawan dan manajemen perusahaan sering terjadi, dimana manajemen perusahaan menggunakan sistem imbalan yang dianggap tidak adil atau tidak layak oleh karyawan. Hal ini akan memicu konflik dalam bentuk pemogokan yang merugikan karyawan, perusahaan, konsumen dan pemerintah.

7. Komunikasi yang tidak baik.

Komunikasi yang tidak baik sering kali menimbulkan konflik dalam organisasi. Faktor komunikasi yang menyebabkan konflik, misalnya distorsi, informasi yang tidak tersedia dengan bebas, dan penggunaan kata yang tidak dimengerti oleh pihak- pihak yang melakukan komunikasi.Demikian juga, perilaku komunikasi yang berbeda sering kali menyinggung orang lain, baik disengaja maupun tidak disengaja dan bias menjadi penyebab timbulnya konflik.

8. Perlakuan tidak manusiawi.

Dengan berkembangnya masyarakat madani dan adanya undang-undang hak asasi manusia di Indonesia, pemahaman dan sensitivitas anggota masyarakat terhadap hak asasi manusia dan penegak hukum semakin meningkat. Perlakuan yang tidak manusiawi dan melanggar hak asasi manusia di masyarakat maupun di organisasi dapat menimbulkan perlawanan dari pihak yang mendapat perlakuan tidak manusiawi. Beragamnya karakteristik sistem sosial

\section{METODOLOGI PENELITIAN}

Penelitian ini merupakan bentuk penelitian deskriptif kuantitatif, yaitu data dikumpulkan dalam bentuk numerik yang dapat dihitung, dihasilkan dari pengumpulan hasil dari kuesioner yang disebarkan dan terkait dengan kajian yang diteliti.. Dalam penelitian ini yang menjadi populasi adalah seluruh karyawan PT. CAP (Citra Aqila Proteksi) Medan yang berjumlah 43 orang.

Batasan operasional variabel yang akan diteliti adalah:

1) Variabel Bebas (independent variabel) merupakan variabel berpengaruh atau variable dianggap dapat mengakibatkan perubahan atau dapat menimbukan variabel terikat. Variabel bebas yang dikaji disini adalah variabel Stress $\left(\mathrm{X}_{1}\right)$ dan Konflik kerja $\left(\mathrm{X}_{2}\right)$

2) Variabel terikat (dependent variabel) disini adalah variabel berpengaruh atau variable yang ditetapkan sebagai akibat dengan adanya variabel bebas ini. dimana kinerja karyawan (Y) menjadi variabel terikat dalam kajian ini

Berdasarkan pemikiran diatas maka kerangka konseptual dapat dibuat secara sistematis sebagai berikut:

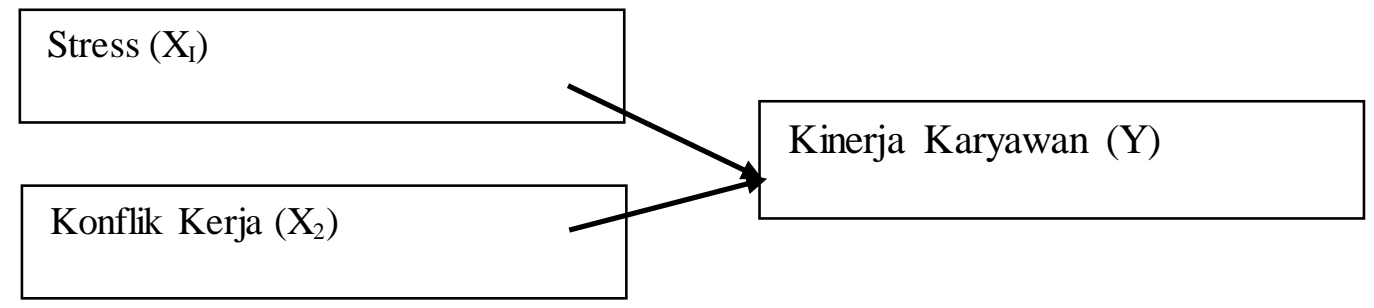

Gambar 1. Kerangka Konseptual 
Teknik Analisi Data menggunakan Analisis Statistik Deskriptif, yang digunakan untuk mengetahui distribusi item-item dari Variabel Stress Kerja (X1), Konflik Kerja (X2), dan Kinerja (Y) yang diperoleh melalui kuesioner, dalam bentuk jumlah responden dan persentase.

Analisis data penelitian ini menggunakan analisis regresi linear berganda karena jumlah variabel yang diteliti lebih dari satu. Analisis regresi linear berganda digunakan untuk mengetahui pengaruh antara variabel independen (Stress, Konflik Kerja) terhadap variabel dependen (Kinerja Karyawan) pada Karyawan PT. Citra Aqila Proteksi

\section{HASIL DAN PEMBAHASAN}

Tabel 4 berikut ini menunjukkan hasil estimasi regresi melalui pengolahan data dengan SPSS.

\begin{tabular}{|c|c|c|c|c|c|c|c|c|}
\hline & \multirow{2}{*}{ Model } & \multicolumn{2}{|c|}{$\begin{array}{l}\text { Unstandardized } \\
\text { Coefficients }\end{array}$} & \multirow{2}{*}{$\begin{array}{c}\begin{array}{c}\text { Standardized } \\
\text { Coefficients }\end{array} \\
\text { Beta }\end{array}$} & \multirow{2}{*}{$t$} & \multirow{2}{*}{ Sig. } & \multicolumn{2}{|c|}{ Collinearity Statistics } \\
\hline & & $B$ & Std. Error & & & & Tolerance & VIF \\
\hline \multirow[t]{3}{*}{1} & (Constant) & 53.002 & 4.244 & & 12.488 & .000 & & \\
\hline & Stres_Kerja & -.194 & .036 & -.623 & -5.369 & .000 & .967 & 1.034 \\
\hline & Konflik_Kerja & -.402 & .107 & -.436 & -3.757 & .001 & .967 & 1.034 \\
\hline
\end{tabular}

Berdasarkan hasil pengolahan data yang ditunjukkan dalam Tabel 4,maka diperoleh persamaan regresi linear berganda dengan rumus sebagai berikut :

Dimana :

$$
\mathrm{Y}=53,002-0,194 \mathrm{X}_{1}-0,402 \mathrm{X}_{2}+\mathrm{e}
$$

$\mathrm{Y} \quad=$ Kinerja Karyawan

$\mathrm{a}=$ Konstanta

$\mathrm{X}_{1}=$ Stress

$\mathrm{X}_{2}=$ Konflik Kerja

$\mathrm{b}_{1,2}=$ Koefisien regresi

e $=$ Standard error

Interpretasi :

a) Konstanta (a) =53,002 artinya bahwa apabila variabel bebas secara keseluruhan (variabel stress dan konflik kerja) berada pada posisi nol (0), variabel terikat (kinerja karyawan) akan berada di posisi tetap sebesar 53,002.

b) Nilai koefisien untuk variable $\mathrm{X}_{1}$ (stress) sebesar negatif 0,194. Maka dapat ditangkap maknanya dimana bila terjadi perubahan naik variable stress satu satuan, hal ini akan berdampak menimbulkan perubahan menurun variabel Y (kinerja karyawan) senilai 0,0194, pada anggapan variabel bebas lainnya pada model regresi nilainya tidak berubah. Sehingga dapat diartikan bahwa dalam kajian ini variabel stress akan memberikan pengaruh negatif terhadap kinerja karyawan. Jika stres kerja meningkat maka kinerja karyawan outsourching PT. CAP akan menurun signifikan, demikian sebaliknya.

c) Koefisien koefisien untuk variable $\mathrm{X}_{2}$ (konflik kerja) sebesar negatif 0,402. Hal ini mengandung arti bahwa setiap kenaikan Konflik Kerja satu satuan maka variabel Y (kinerja karyawan) akan turun sebesar 0,402 dengan asumsi bahwa variabel bebas yang lain dari model regresi adalah tetap. Disimpulkan, variabel konflik kerja berpengaruh negatif bila 
dihubungkan dengan kinerja karyawan PT. CAP. Jika konflik kerja meningkat maka kinerja karyawan outsourching PT. KAM akan menurun signifikan, demikian sebaliknya.

Berdasarkan tabel 4 Uji Parsial juga terlihat bahwa:

1) Pengaruh variabel stress $\left(\mathrm{X}_{1}\right)$ terhadap kinerja karyawan $(\mathrm{Y})$ : Dapat diperhatikan bahwa didapatkan data pada kolom Coefficients model 1 nilai sig 0,000 . Nilai sig didapatkan lebih kecil dibanding nilai probabilitas 0,05 , yaitu nilai $0,000<0,05$. Dengan hasil ini dapat dimaknakan $\mathrm{H}_{\mathrm{a}}$ diterima dan $\mathrm{H}_{0}$ ditolak. Variabel X1 diperoleh $\mathrm{t}_{\text {hitung }}$ senilai 5,369 bertepatan $t_{\text {tabel }}$ senilai 1,986. Dari hasil kajian $t_{\text {hitung }}>t_{\text {tabel }}$ bisa diartikan variabel $X_{1}$ mempunyai kontribusi signifikan kepada variabel $Y$. Nilai $t$ yang berada pada posisi negatif memberikan makna dimana $X_{1}$ memiliki relasi bertolak belakang terhadap variabel Y. Maka dari bagian ini, bisa ditarik makna bahwa variable stress menimbulkan pengaruh yang signifikan dengan arah terbalik terhadap kinerja karyawan pada PT. CAP.

Berdasarkan distribusi jawaban responden terhadap variabel stress kerja terdapat 43 orang responden mendapat tanggapan cenderung kurang setuju. Saya diberikan wewenang yang cukup untuk melaksanakan pekerjaan saya merupakan hasil skor tertinggi dari item stres kerja, hal ini disebabkan karena karyawan outsourching tidak punya kebebasan yang cukup dalam melaksanakan kegiatan didalam perusahaan, sehingga ketika ada kendala dilapangan karyawan harus menunggu intruksi terlebih dari atasan untuk tindakan apa yang harus dikerjakan. Kebijakan seperti ini lama kelamaan dapat menurunkan kinerja dari karyawan outsourching karena terbiasa menunggu intruksi dari atasan menjadikan inisiatif mereka berkurang. Kemudian item stres tertinggi adalan dalam pernyataan ketidakjelasan kontrak kerja. Dengan adanya kejelasan status pekerjaan akan menumbuhkan rasa aman didalam melakukan pekerjaan, namun jika kontrak kerja belum diterima oleh karyawan outsourching maka mereka akan merasa cemas dan hal ini dapat menurunkan semangat bekerja mereka yang tentunya akan berdampak kepada penurunan kinerja dari karyawan tersebut.

2) Pengaruh variabel konflik kerja $\left(\mathrm{X}_{2}\right)$ terhadap kinerja karyawan pada PT. CAP $(\mathrm{Y})$ : Terlihat pada kolom Coefficients model 1 terdapat nilai sig 0,001. Nilai sig lebih kecil dari nilai probabilitas 0,05 , atau nilai $0,001<0,05$, maka $\mathrm{H}_{\mathrm{a}}$ diterima dan $\mathrm{H}_{0}$ ditolak. Variabel $\mathrm{X} 2$ mempunyai $t_{\text {hitung }}$ yakni 3,757 dengan $t_{\text {tabel }}$ sebesar 1,986. Jadi $t_{\text {hitung }}>t_{\text {tabel }}$, sehingga dapat disimpulkan bahwa variabel $\mathrm{X}_{2}$ memiliki kontribusi signifikan terhadap $\mathrm{Y}$. Nilai $\mathrm{t}$ negatif menunjukkan bahwa variabel $\mathrm{X}_{2}$ mempunyai hubungan yang berbanding terbalik dengan $\mathrm{Y}$. Jadi dapat disimpulkan konflik kerja memiliki pengaruh signifikan terbalik bila berhubungan dengan kinerja karyawan pada PT. CAP. Jika konflik kerja meningkat maka kinerja karyawan menurun signifikan, demikian sebaliknya.

Berdasarkan penelitian terhadap variabel konflik kerja yang telah disebar kepada 43 responden, menunjukkan bahwa pernyataan konflik kerja mendapat tanggapan cenderung setuju. Namun ada beberapa karyawan yang juga menjawab kurang setuju dengan pernyataan mengenai konflik kerja. Konflik dengan pihak manajemen outsourching PT CAP terkait masalah hak dan kewajiban memiliki skor tertinggi yaitu pada pernyataan ke delapan (Saya merasa ketidakjelasan status kerja dari pihak perusahaan menimbulkan ketegangan dalam bekerja). Pernyataan yang menunjukkan skor rendah terdapat pada pernyataan ke satu (adanya rasa iri hati terhadap karyawan lainnya, yang berakibat terjadi konflik yang tidak dapat dihindari), karyawan outsourching merasa tidak puas dengan pihak manajemen PT CAP karena tugas dan imbalan tidak sesuai, sehingga kinerjanya menurun. Hal ini ditunjukkan dengan susahnya karyawan outsourching untuk bekerja di hari libur (sabtu \& minggu), karena tidak jelasnya perhitungan upah lembur yang diberikan pada saat hari libur. Perbedaan pendapat dengan rekan kerja dalam menentukan solusi atas permasalahan yang berkaitan dengan pekerjaan adalah hal yang wajar didalam sebuah perusahaan. Konflik terhadap rekan kerja dapat menurunkan kinerja karyawan. Konflik pada rekan kerja ditunjukkan dengan komunikasi dan interaksi yang kurang baik antar sesama karyawan dengan karyawan lainnya. Hal itu menciptakan suasana yang tidak kondusif dan hubungan yang kurang baik sehingga kinerja karyawan menurun.

Gambaran seberapa besar perubahan atau variasi suatu variabel bisa diterangkan oleh perubahan atau variasi variabel lainnya ditampilkan oleh koefisien determinasi (Santosa\&Ashari, 2005:125). 
Kisaran nilai koefisien ini berada diantara angka 0 dan angka 1. Apabila didapatkan hasil kajian semakin mendekati angka 1, maka dapat diambil makna bahwa variabel-variabel independen (pengaruh variabel bebas, yang terdiri dari stress dan konflik kerja) memberikan hampir semua informasi yang dibutuhkan untuk memprediksi variasi variabel dependen (kinerja karyawan). Hal ini berarti model yang digunakan semakin kuat untuk menerangkan pengaruh variabel bebas yang diteliti terhadap variabel terikat.

Sebaliknya, jika nilai $\mathrm{R}^{2}$ suatu regresi semakin kecil atau mendekati angka nol, maka dapat dikatakan bahwa pengaruh variabel bebas (stress dan konflik kerja) semakin kecil terhadap variabel terikat (kinerja karyawan pada PT. CAP). Hal ini berarti model yang digunakan tidak kuat untuk menerangkan pengaruh variabel bebas yang diteliti terhadap variabel terikat. Untuk analisisnya dengan menggunakan output SPSS dapat dilihat pada tabel "Model Summary".

Tabel 5. Koefisien Determinasi $\left(\mathrm{R}^{2}\right)$

Model Summary

\begin{tabular}{|l|r|r|r|c|}
\hline Model & R & R Square & $\begin{array}{c}\text { Adjusted R } \\
\text { Square }\end{array}$ & $\begin{array}{c}\text { Std. Error of the } \\
\text { Estimate }\end{array}$ \\
\hline 1 & $.692^{\mathrm{a}}$ & .479 & .453 & 2.10242 \\
\hline
\end{tabular}

a. Predictors: (Constant),Konflik_Kerja, Stres_Kerja

b. Dependent Variable: Kinerja_Karyawan

Sumber: Hasil Penelitian, 2021 (data diolah)

Berdasarkan Tabel 5 dapat dilihat bahwa Angka R Square $\left(\mathrm{R}^{2}\right)$ sebesar 0,479 (47,9\%) menunjukkan bahwa variabel stress $\left(\mathrm{X}_{1}\right)$ dan konflik kerja $\left(\mathrm{X}_{2}\right)$ berpengaruh sebesar 47,9\%. terhadap kinerja karyawan(Y). Adapun selebihnya dengan kisaran 52,1\% bisa diterangkan oleh faktor lain yang tidak dikaji pada penelitian ini.

Nilai R Square yang dapat dilihat hamper mencapai 50\% membuat dapat diartikan bahwa kemampuan variabel-variabel bebas menjelaskan variasi variable adalah terbatas.

Secara umum, hasil penelitian berdasarkan analisis pengaruh stress dan konflik kerja terhadap kinerja karyawan pada PT. CAP, berdasarkan uji signifikansi parsial, menunjukkan:

1) Pada data Uji regresi linear didapatkan nilai konstanta (a) $=53,002$, hal ini menunjukkan dimana pada saat keseluruhan variabel bebas (variabel stress dan konflik kerja) berada pada posisi nilai nol (0), dalam hal ini nilai variabel terikat (kinerja karyawan) akan tidak bergerak pada posisi nilai 53,002. Maka terlihat bahwa tanpa semua variable bebas, nilai variabel terikat (kinerja karyawan pada PT. CAP) sudah mempunyai nilai yang besar.

2) Stress berpengaruh negatif dan signifikan terhadap kinerja karyawan PT. CAP. Pengaruh negatif terlihat dari koefisien untuk variable $X_{1}$ (Stress) sebesar negatif 0,194. Maka dari hasil ini dapat diartikan dimana terjadi perubahan naik variabel stress satu satuan, pada saat itu variabel Y (kinerja karyawanPT. CAP) mengalami perubahan turun senilai 0,194 dimana asumsinya variabel tidak terikat lainnya pada model regresi dalam kajian ini bernilai tetap. Pada hasil Uji Parsial variabel Stress $\left(\mathrm{X}_{1}\right)$ berhubungan dengan kinerja karyawan (Y), dapat diamati hasil di kolom Coefficients model 1 mendapatkan nilai sig 0,000. Dengan nilai sig yang lebih kecil dbanding nilai probabilitas 0,05 , atau nilai $0,000<0,05$, disini dapat diartikan bahwa $\mathrm{H}_{\mathrm{a}}$ diterima dan $\mathrm{H}_{0}$ ditolak. Selanjutnya dengan hasil variabel $\mathrm{X}_{1}$ yang didapatkan mendapatkan $t_{\text {hitung }}$ senilai 5,369 dengan $t_{\text {tabel }}$ sebesar 1,986. Dari hasil $t_{\text {hitung }}>t_{\text {tabel }}$ disini bisa diambil kesimpulan variabel $\mathrm{X}_{1}$ mempunyai kontribusi signifikan pada Y. Selain itu nilai $t$ yang berada pada posisi negatif memberi makna variabel $X_{1}$ memiliki hubungan yang tidak searah terhadap variable Y. Sehingga pada posisis ini dapat diartikan variabel Stress 
memiliki pengaruh signifikan negatif dila dihubungkan dengan kinerja karyawan pada PT. CAP.

3) Pengaruh secara negatif dan signifikan terlihat dari hubungan variabel konflik kerja terhadap kinerja karyawan PT. CAP. Kesimpulan ini dapat dilihat dari dua hal. Pertama, dari nilai koefisien untuk variable $\mathrm{X}_{2}$ (konflik kerja) sebesar 0,402. Dari hal dapat diartikan dimana setiap terjadi kenaikan pada variable konflik kerja senilai satu satuan, variabel Y (kinerja karyawan PT. CAP) mengalami perubahan turun senilai 0,402, dimana asumsinya variabel bebas lain yang dikaji dalam model regresi adalah tetap. Melihat hasil uji parsial pada kolom Coefficients model 1, kita mendapati adanya nilai sig 0,001 . Dengan nilai sig yang bernilai lebih kecil dibanding nilai probabilitas 0,05 , atau $0,001<0,05$, maka dapat dimaknakan $\mathrm{Ha}$ diterima dan H0 ditolak. Sedangkan dari variabel X2 yang memiliki $t_{\text {hitung }}$ senilai 3,757 dengan $t_{\text {tabel }}$ sebesar 1,986, sehingga $t_{\text {hitung }}>t_{\text {tabel }}$, maka bisa diambil makna $X_{2}$ memiliki kontribusi terhadap $Y$. Nilai t negatif menjelaskan dimana variabel $\mathrm{X}_{2}$ memiliki hubungan terbalik terhadap Y. Dapat disimpulkan disini, konflik kerja mempunyai pengaruh signifikan negatif bila dihubungan kepada kinerja karyawan PT. CAP.

\section{KESIMPULAN}

Berdasarkan hasil dari pembahasan, dapat disimpulkan bahwa:

1) Secara Parsial Variabel Stress $\left(X_{1}\right)$ dapat disimpulkan memiliki pengaruh negatif signifikan kepada variabel kinerja karyawan pada PT. Citra Aqila Proteksi Medan. Hasil penelitian menunjukkan bahwa variabel stres kerja berpengaruh negatif dan signifikan terhadapkinerja karyawan. Nilai koefisien stres kerja adalah $-0,194$, yakni bernilai negatif dengan nilai $t_{\text {hitung }}$ $(-5,369)<t_{\text {tabel }}(2,021)$ dan signifikansi $(0,000)<0,05$. Jika stres kerja meningkat maka kinerja karyawan menurun signifikan, demikian sebaliknya

2) Secara parsial, dapat ditarik kesimpulan Variabel konflik kerja $\left(X_{2}\right)$ memiliki pengaruh negatif dan signifikan kepada variabel kinerja karyawan pada PT. Citra Aqila Proteksi Medan. Nilai koefisien konflik kerja adalah $-0,402$, yakni bernilai negatif dengan nilai $t_{\text {hitung }}$ $(-3,757)<\mathrm{t}_{\text {tabel }}(2,021)$ dan signifikansi $(0,000)<0,05$. Jika konflik kerja meningkat maka kinerja karyawan menurun signifikan, demikian sebaliknya

3) Variabel Stress dan Konflik Kerja secara serempak berpengaruh signifikan terhadap variabel kinerja karyawan pada PT. Citra Aqila Proteksi Medan. Nilai R Square $\left(\mathrm{R}^{2}\right)$ sebesar 0,479 $(47,9 \%)$ menjelaskan pada kajian ini dimana variabel Stress $\left(\mathrm{X}_{1}\right)$ dan Konflik Kerja $\left(\mathrm{X}_{2}\right)$ memiliki pengaruh senilai 47,9\%. kepada variable Kinerja Karyawan (Y). Pengaruh lainnya dengan nilai $52,1 \%$ diterangkan oleh faktor-faktor lain yang tidak diteliti dalam penelitian ini.

Berdasarkan kesimpulan yang diatas maka ada beberapa hal yang disarankan peneliti sebagai berikut:

1) Untuk mengurangi faktor stres kerja, maka sebaiknya perusahaan dapat meningkatkan kolaborasasi antar atasan dan karyawan. Dengan semakin eratnya hubungan antara atasan dan bawahan dan terjalinnya team work yang bagus, maka diharapkan dapat mengurangi rasa tidak nyaman dan memberikan peluang bagi karyawan untuk mengeluarkan pendapat untuk dapat di pertimbangkan oleh atasan sehingga adanya keleluasaan para karyawan dalam melakuan tugas dan wewenang serta mengurangi ketegangan antara pihak perusahaan dengan karyawan yang merupakan salah satu penyebab tingginya faktor stres kerja di perusahaan. Kemudian diharapkan kepada pihak perusahaan agar memberikan kejelasan tentang kontrak kerja karyawan sehingga tidak menimbulkan rasa tertekan dalam melaksanakan pekerjaan.

2) Saran untuk faktor konflik kerja yaitu agar lebih memperhatikan faktor kebutuhan dari karyawan seperti memberikan kejelasan tentang status karyawan dan pengakuan akan kinerja karyawan, menyesuaikan hak dan kewajiban karyawan dan memberikan kenyamanan bagi karyawan yang berkerja sehingga terciptanya motivasi dan semangat kerja 
karyawan. Kemudian bagi karyawan harus menggali informasi sebelum melakukan pekerjaan sehingga tidak terjadi kesalahan dan perdebatan dalam bekerja.

3) Adapun saran untuk faktor stres kerja yang paling efektif harus ada kolaborasasi antar atasan dan karyawan, makin mempererathubungan antara atasan dan bawahan dan terjalinnya team work yang bagus sehingga dapat mengurangi rasa tidak nyaman dan memberikan peluang bagi karyawan untuk mengeluarkan pendapat untuk dapat di pertimbangkan oleh atasan sehingga adanya keleluasaan para karyawan dalam melakuan tugas dan wewenang serta mengurangi ketegangan antara pihak perusahaan dengan karyawan yang merupakan salah satu penyebab tingginya faktor stres kerja di perusahaan. Kemudian diharapkan kepada pihak perusahaan agar memberikan kejelasan tentang kontrak kerja karyawan sehingga tidak menimbulkan rasa tertekan dalam melaksanakan pekerjaan.

4) Efek terjadinya konflik dan stres pada karyawan tergantung pada sifat-sifat individu karyawan dan environ lainnya faktor mental yang dapat mengakibatkan penurunan performa pada kinerja karyawan. Di sisi lain strategi manajemen yang baik pada perusahaan bagi karyawan adalah melibatkan kombinasi keterampilan mengatasi masalah pribadi, rencana organisasi yang efektif dan dukungan sosial. Dengan kata lain kebijakan perusahaan dalam pengelolaan pegawai untuk mengatasi konflik dan stres kerja stres saling terkait dalam mempengaruhi kinerja karyawan. Diharapkan kedepannya pihak perusahaan dapat mempertimbangkan hak dan kewajiaban para karyawan dan memberikan kenyamanan dalam bekerja sehingga dapat meminimalkan konflik yang juga dapat mengakibatkan stres (beban) para karyawan.

Karena keterbatasan yang dimiliki oleh peneliti, diharapkan kepada peneliti selanjutnya untuk dapat lebih menyempurnakan penelitian ini, dengan menggunakan faktor-faktor lain selain yang diteliti oleh peneliti. Adapun faktor-faktor lain yang dianggap penulis penting adalah motivasi kerja, lingkungan kerja dan gaya kepemimpinan.

\section{REFERENSI}

[1] Astianto, A., \& Suprihhadi, H. (2014). Pengaruh Stres kerja dan Beban kerja Terhadap kinerja karyawan PDAM Surabaya, Jurnal Ilmu dan Riset Manajemen, Vol. 3, No. 7, Malang: STIEI Malang

[2] Edwin B Flippo (2012), Personel Management(Manajemen Personalia), Edisi. VII Jilid II, Terjemahan Alponso S, Erlangga, Jakarta

[3] Edwin B. Flippo (2013), Manajemen SDM dalam Organisasi Publik dan Bisnis, Edisi Keenam, Alih Bahasa : Dr. H Suwanto \& Donni Juni Priansa, S.Pd., Cv Alfabeta. Jakarta

[4] Elizabeth George dan K.A. Zakkariya (2015), Job Related Stress And Job Satisfaction: A Comparative Study Among Bank Employees, Journal of Management Development, Volume 34 No. 3, Emerald Publishing, Bingley

[5] Job related stress and job satisfaction: a comparative study among bank employees

[6] Faustino Cardoso Gomes (2013), Manajemen Sumber Daya Manusia, Andi, Yogyakarta

[7] Gary Dessler (2015), Manajemen Sumber Daya Manusia, Edisi: 14, Alih Bahasa: Diana Angelica, Salemba Empat, Jakarta

[8] Malayu Hasibuan (2016), Manajemen Sumber Daya Manusia.Penerbit Bumi Aksara, Jakarta

[9] Stephen P. Robbins (2015), Organizational Behavior, 9th Edition, Precentice Hall International Inc., New Jersey 
[10] Stephen P. Robbins dan Mary Coulter (2016), Manajemen, Jilid 1 Edisi 13, Alih Bahasa: Bob Sabran Dan Devri Bardani P, Erlangga, Jakarta

[11] Sugiyono (2010), Metode Penelitian Kuantitatif, Kualitatif, dan R\&D, penerbit Alfabeta, Bandung 